\title{
KUALITAS LAYANAN DAN KEPUASAN KONSUMEN: PERSEPSI MASYARAKAT SURABAYA TERHADAP RESTORAN JEPANG DI KOTA SURABAYA
}

\author{
Endo W. Kartika \\ Program Manajemen Perhotelan, Fakultas Ekonomi, Universitas Kristen Petra \\ Jl. Siwalankerto 121-131, Surabaya \\ E-mail: endo@petra.ac.id
}

\begin{abstract}
Abstrak: Penelitian ini bertujuan untuk menentukan indikator-indikator pembentuk kualitas layanan berdasarkan sudut pandang konsumen masyarakat Surabaya pada restoran Jepang yang ada di Surabaya agar dapat menciptakan kepuasan, serta pengaruh dari kualitas layanan tersebut terhadap kepuasan konsumennya. Penelitian ini dilakukan terhadap 100 orang responden masyarakat Surabaya dengan menggunakan pengukuran DineSERV berdasarkan Stevens, Knutson, \& Patton (1995). Analisis yang digunakan adalah Confirmatory Factor Analysis dengan bantuan SmartPLS 2.0, dan Multiple Linear Regression dengan menggunakan SPSS 23. Hasil penelitian menunjukkan bahwa keseluruhan indikator pada DineSERV dapat diterapkan sebagai indikator pembentuk kepuasan masyarakat Surabaya, sedangkan hasil pengaruh kepuasan layanan terhadap kepuasan konsumen menunjukkan bahwa dimensi tangible dan assurance memiliki pengaruh positif namun tidak signifikan, dimensi reliability dan empathy memiliki pengaruh positif dan signifikan, sedangkan dimensi responsiveness memiliki pengaruh negatif namun tidak signifikan.
\end{abstract}

Kata kunci: Kualitas layanan, kepuasan konsumen, DineSERV

\begin{abstract}
The aim of the research is to identify the construct indicators for service quality based on the Japanese restaurants customer's perspective in Surabaya, and explain the impact on service quality towards consumer satisfaction. A total of 100 people residing in Surabaya as respondents took part on the research using the DineSERV measurement by Stevens, Knutson, \& Patton (1995). The analysis which are conducted consist of the Confirmatory Factor Analysis using SmartPLS 2.0 software, and Multiple Linear Regression using SPPS 23. The findings indicate that DineSERV can be applied as the construct indicators for service quality based on the people of Surabaya. Further result indicates that tangible and assurance dimension were positively but not significantly affect customer satisfaction; reliability and empathy were positively and significantly affect customer satisfaction; and responsiveness was negatively but not significantly affect customer satisfaction.
\end{abstract}

Keywords: Service quality, customer satisfaction, DineSERV.

\section{PENDAHULUAN}

Konsep kualitas layanan masih menjadi topik yang paling banyak dikaji dan diuji secara empiris oleh banyak praktisi maupun peneliti yang khususnya berada di industri jasa (Caruana, 2002).Tak terkecuali di industri makanan dan minuman seperti restoran dan kafe, konsep kualitas layanan ini walaupun dalam konteks sederhana ataupun kompleks tidak dapat dipungkiri tetap menjadi sebuah indikator bagi penyedia jasa yang harus disediakan serta menjadi indikator bagi konsumen apakah layak untuk dikunjungi dan dapat memberikan pelayanan yang baik.

Arah dari kualitas layanan yang baik, diharapkan mampu untuk memberikan kepuasan bagi setiap konsumen yang datang dan menikmati layanan yang diberikan. Oleh karena itu kualitas layanan hanya dapat dilihat dari sudut pandang konsumen, yang mana muncul sebuah persepsi yang ada di benak setiap konsumen sebagai penilaian apa yang dirasakan dalam mendapatkan sebuah jasa pelayanan. Setiap konsumen memiliki persepsi dan sekaligus ekspektasi terhadap setiap kualitas layanan yang diberikan oleh penyedia jasa, apabila persepsi atas kualitas layanan yang diterima lebih rendah daripada ekspektasi yang ada maka dapat dikatakan bahwa kualitas layanan tersebut buruk dan dapat menyebabkan ketidakpuasan konsumen, sebaliknya apabila persepsi atas kualitas layanan yang diberikan sesuai atau bahkan lebih tinggi daripada ekspektasi yang ada maka dapat dikatakan bahwa kualitas layanan tersebut baik dan dapat menyebabkan kepuasan konsumen (Zeithaml, Bitner, \& Gremler, 2006).

Dalam industri restoran dan kafe, tingkat persaingan yang terjadi semakin tinggi sehingga setiap konsumen dihadapkan pada alternatif yang jauh lebih banyak dan bervariasi terkait produk, jasa, harga, dan kualitas, yang mana pada akhirnya setiap konsumen akan berusaha mencari nilai yang dianggap paling 
tinggi (Kotler \& Keller, 2009). Pada akhirnya konsumen akan menilai kualitas layanan yang ada apakah memuaskan atau tidak, dan ketidakpuasan konsumen akan memungkinkan untuk berujung pada kekecewaan yang mana memiliki kecenderungan untuk bercerita tentang keburukan yang ada kepada 15 orang lainnya, dan sebagai dampak akhir konsumen akan meninggalkan dan menjatuhkan pilihannya kepada pesaing (Lupiyoadi \& Hamdani, 2006). Akan tetapi, ketika konsumen menilai bahwa kualitas layanan tersebut dianggap baik dan memuaskan, hal ini dapat menyebabkan kunjungan konsumen secara rutin, terciptanya loyalitas, dan kemudian akan mengarah kepada terciptanya word of mouth (Tjiptono, 2005).

Penelitian ini menitikberatkan kepada restoranrestoran Jepang yang ada di kota Surabaya, yang secara mayoritas akan memberikan kualitas layanan yang terbaik bagi setiap konsumen yang datang. Akan tetapi, seringkali pihak penyedia jasa kurang peka terhadap indikator-indikator yang dari sudut pandang konsumen dianggap penting untuk dapat menciptakan kepuasan konsumen. Restoran Jepang yang ada di kota Surabaya, sebagian besar didominasi oleh restoran franchise yang memungkinkan untuk ditemui di hampir setiap kota besar baik di Indonesia maupun di luar negeri, beberapa stand-alone restoran yang dimiliki oleh warga negara Jepang maupun warga negara Indonesia. keberadaan lokasi restoran tersebut cukup banyak yang terintegrasi ke dalam mall, beberapa terdapat di komplek ruko, dan sisanya berada di pinggir jalan utama kota Surabaya. Di sisi lain, setiap restoran tersebut memiliki persamaan sebagai ciri khas restoran Jepang yaitu penekanan pada pelayanan personal yang baik yang diberikan oleh pramusaji dalam menyajikan makanan dan minuman. Dengan cukup bervariasinya kondisi restoran yang ada, pastinya menjadikan faktor kelebihan maupun faktor kekurangan yang nantinya dapat menjadi pertimbangan setiap konsumen.

Dalam penelitian ini, pengukuran hanya murni berdasarkan aspek-aspek dari 5 dimensi kualitas layanan yaitu reliability, responsiveness, assurance, empathy, dan tangibles sehingga walaupun kondisi restoran Jepang yang ada saat ini bervariasi, akan tetap digolongkan secara homogen. Atas dasar pemikiran tersebut maka rumusan masalah dalam penelitian ini antara lain: identifikasi faktor-faktor kelima dimensi kualitas layanan pembentuk kepuasan konsumen pada restoran Jepang di Surabaya?; dan apakah kelima dimensi kualitas layanan berpengaruh secara positif dan signifikan terhadap kepuasan konsumen restoran Jepang di Surabaya?

\section{LANDASAN TEORI DAN HIPOTESIS}

\section{Kualitas Layanan}

Kotler \& Armstrong (2003) berpendapat bahwa kualitas layanan merupakan keistimewaan dan karakteristik dari produk atau jasa secara menyeluruh dapat mampu untuk memuaskan kebutuhan secara langsung maupun tidak langsung, yang dapat diukur dari persepsi pembeli yang mana kualitas layanan yang memuaskan dapat memberikan gambaran positif bagi penyedia jasa, begitu juga sebaliknya apabila mengecewakan akan memberikan gambaran yang negatif.

Kualitas layanan dapat diukur melalui 5 dimensi yang meliputi reliability, responsiveness, assurance, empathy, dan tangibles (Zeithaml \& Bitner, 2009). Dimensi pertama yaitu reliability mengarah kepada sejauh mana penyedia jasa dapat memberikan layanan secara konsisten sesuai dengan yang telah dijanjikan untuk diberikan kepada konsumen. Dalam konteks konsumen Asia, kebanyakan konsumen akan menitikberatkan pada dimensi ini di dalam mendapatkan kualitas layanan yang dapat diandalkan (Kotler, et al., 1999). Dimensi kedua yaitu responsiveness mengarah kepada keinginan penyedia jasa untuk membantu konsumen serta menyediakan jasa yang sesuai secara cepat dan tanggap terhadap kebutuhan konsumen. Dari perspektif konsumen Asia, beberapa konsumen dari negara di Asia yang beranggapan bahwa waktu berputar dan akan kembali lagi cenderung untuk tidak terlalu menghargai responsiveness dari layanan yang didapatkan, sebaliknya beberapa konsumen dari Hong Kong atau Singapura yang beranggapan bahwa waktu bersifat linier yang tidak memungkinkan untuk diputar ulang cenderung sangat menekankan pada responsiveness karena akan membuang waktu dengan sia-sia (Kotler, et al., 1999). Dimensi ketiga yaitu assurance mengarah kepada kepada jaminan serta pemberian rasa aman terhadap konsumen yang memerlukan dukungan pengetahuan yang mendukung terkait dengan produk, sikap kesopanan, dan sikap profesional yang diberikan oleh penyedia jasa. Dimensi keempat yaitu empathy mengarah kepada kepedulian dan perhatian dari masing-masing individu penyedia jasa kepada semua konsumen yang diberikan pelayanan.Dalam konteks konsumen Asia, dimensi ini memiliki kecenderungan menjadi faktor yang penting bagi konsumen, sehingga setiap penyedia jasa diharapkan dapat mengutamakan empathy yang dapat ditunjukkan oleh frontliner dalam penyampaian jasa (Kotler, et al., 1999). Dimensi yang terakhir yaitu tangibles mengarah kepada kepada penampilan fasilitas fisik, peralatan pendukung, 
personalia, dan material-material yang dimiliki oleh penyedia jasa untuk mendukung penyampaian jasa kepada konsumen.Konsumen Asia cenderung lebih mementingkan dimensi ini sebagai salah satu bentuk pamor dalam memberikan ataupun mendapatkan sebuah jasa, hal ini bertolak belakang dengan konsumen Amerika yang justru kurang mementingkan dimensi tangibles ini dalam mendapatkan sebuah jasa (Kotler, et al., 1999).

Kualitas layanan yang dimiliki oleh sebuah restoran, diukur dalam bentuk alat ukur yang seringkali digunakan untuk menilai yaitu servqual, akan tetapi telah disesuaikan dengan konteks spesifik yaitu restoran sehingga diberi nama dineserv yang dikemukakan oleh Stevens, Knutson, \& Patton (1995). Alat ukur ini sendiri merupakan modifikasi dari servqual yang mula-mula digunakan untuk membentuk lodgeserv yaitu alat ukur untuk menilai kualitas layanan penginapan, dan kembali dimodifikasi sesuai kebutuhan pengukuran restoran yang terdiri dari 29 butir pernyataan (Stevens, Knutson, \& Patton, 1995).

\section{Kepuasan Konsumen}

Kepuasan konsumen merujuk pada perasaan yang muncul dari seorang konsumen apakah nyaman ataupun kecewa setelah membandingkan suatu produk yang dikemas atau suatu hasil jasa yang disesuaikan dengan harapan konsumen tersebut. Kepuasan konsumen mencakup perbedaan antara harapan dengan hasil yang dirasakan setelah konsumen melakukan transaksi pembelian barang atau jasa.Dalam hal ini kesesuaian antara kenyataan dan harapan konsumen menjadi hal yang menentukan. Sekurang-kurangnya alternatif yang dipilih oleh konsumen agar mencapai rasa puas, adalah kinerja atau hasil yang sama atau melampaui harapan konsumen. Oleh karena itu penyedia jasa harus berusaha dan mampu menumbuhkan dan memelihara kepuasan konsumen, karena hal tersebut akan memberikan keuntungan bagi penyedia jasa itu sendiri (Kotler, 2003).

\section{Kualitas Layanan dan Kepuasan Konsumen}

Persepsi seorang konsumen atas pelayanan yang dirasakan, dapat menjadi indicator sejauh mana konsumen tersebut merasa puas dengan pelayanan yang telah didapatkan.Sehingga kualitas dari pelayanan yang didapatkan dapat juga mempengaruhi sejauh mana seorang konsumen untuk tetap bertahan dan menikmati pelayanan yang diberikan oleh penyedia layanan, serta sejauh mana seorang konsumen menentukan jumlah pembelian atau konsumsi (Wakefield \& Blodgett, 1996).

H1: Kualitas layanan berpengaruh secara positif dan signifikan terhadap kepuasan konsumen

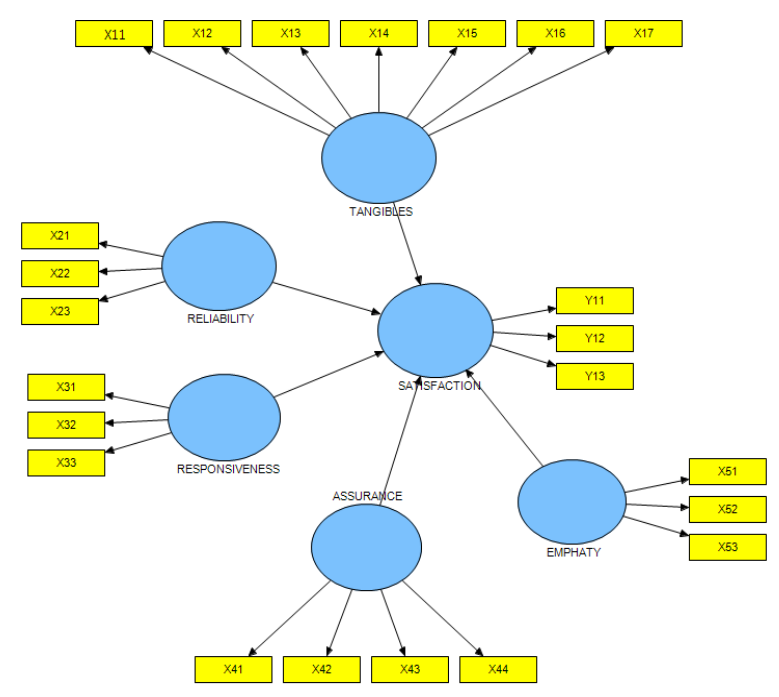

Gambar 1. Model Penelitian

\section{METODE PENELITIAN}

Penelitian ini adalah penelitian kuantitatif eksplanatif, karena bertujuan untuk menjelaskan hubungan diantara dua variabel atau lebih. Populasi yang diambil pada penelitian ini adalah seluruh konsumen restoran Jepang yang berada di kota Surabaya. Pengambilan sampel menggunakan non-probability sampling dengan teknik Judgemental Sampling yang mana dalam pengambilan sampel untuk penelitian ini, ditetapkan beberapa kriteria kelayakan untuk dapat dijadikan sampel. Beberapa kriteria tersebut antara lain berusia minimal 17 tahun; pernah menjadi konsumen restoran Jepang yang ada di kota Surabaya minimal 2 kali dalam kurun waktu 6 bulan terakhir. Jumlah total sampel yang diajukan dalam penelitian ini berjumlah 100 responden, total kuisioner yang disebarkan berjumlah 103 yang mana sejumlah 3 kuisioner tidak kembali.

Variabel yang diteliti meliputi kualitas layanan (X) sebagai variabel independen yang terdiri dari lima dimensi yaitu tangibles (X1); reliability (X2); responsiveness (X3); assurance (X4); empathy (X5); dan kepuasan konsumen (Y) sebagai variabel dependen. Kualitas layanan yang digunakan mengikuti ukuran Dineserv dari Stevens, Knutson, \& Patton (1995) yang disesuaikan dengan kondisi restoran Jepang yang ada di kota Surabaya. 
Tangibles: Indikator dari tangibles cenderung mengarah kepada bentuk fisik tampilan fasilitas, perlengkapan, dan penampilan karyawan yang secara langsung tampak terlihat oleh konsumen. Beberapa contoh indikator yang digunakan seperti "penampilan karyawan tampak bersih rapi", "dekorasi interior restoran sesuai dengan tema restoran Jepang".

Reliability: Indikator dari reliability mengarah kepada sejauh mana kemampuan dari penyedia jasa untuk menunjukkan pelayanan yang dapat diandalkan dan akurat. Contoh indikator yang digunakan seperti "karyawan cepat memberikan tindakan korektif apabila ada sesuatu yang salah", "kesesuaian makanan yang disajikan dengan yang dipesan".

Responsiveness: Indikator dari responsiveness cenderung mengarah pada sejauh mana karyawan memiliki kesediaan untuk memberikan pelayanan kepada konsumen dan menyediakan pelayanan yang tepat waktu. Beberapa indikator yang digunakan yaitu "kecepatan layanan yang diberikan kepada konsumen", "kemauan karyawan untuk saling membantu satu dengan yang lainnya".

Assurance: Indikator dari assurance mengarah kepada pengetahuan yang dimiliki oleh karyawan, keramahan yang ditunjukkan, serta kemampuan yang dapat meyakinkan dan menimbulkan kepercayaan dari konsumen. Contoh indikator yang digunakan seperti "kemampuan karyawan untuk memberikan informasi terkait menu, bahan dasar, dan cara pengolahan makanan", "karyawan terlihat terlatih dan berpengalaman".

Empathy: Indikator empathy mengarah kepada kemampuan karyawan dalam menyediakan pelayanan dengan menunjukkan perhatian yang penuh dan eksklusif. Beberapa contoh indikator yang digunakan seperti "karyawan memberikan perasaan simpati kepada setiap konsumen", "kesediaan karyawan untuk selalu membantu konsumen".

\section{HASIL ANALISIS DAN PEMBAHASAN}

\section{Profil Deskriptif Responden}

Berdasarkan hasil kuisioner ditemukan bahwa mayoritas responden pada penelitian ini adalah perempuan $(61 \%)$, mayoritas usia responden pada kisaran 26-35 tahun (45\%) dan 36-45 tahun (38\%), pada konteks pekerjaan responden mayoritas adalah pegawai swasta (59\%). Terkait dengan pendapatan responden tiap bulan mayoritas berkisar pada $\mathrm{Rp}$ 10.000 .000 - Rp 15.000.000 (47\%) dan Rp 5.000.000 - Rp 10.000.000 (31\%), frekuensi kedatangan setiap bulan di restoran Jepang mayoritas berkisar 5-7 kali dalam sebulan $(42 \%)$.
Analisis deskriptif dilakukan untuk melihat nilai mean pada masing-masing indikator, yang mana dalam penelitian ini digunakan skala likert 1-7, dengan rentang nilai 1 adalah sangat tidak setuju sekali dan 7 adalah sangat setuju sekali. Untuk kategori dari hasil nilai mean menggunakan 7 kategori kelas dengan rentang dari sangat buruk sekali sampai dengan sangat baik sekali.

Tabel 1. Kategori Kelas

\begin{tabular}{c|l}
\hline Mean & \multicolumn{1}{c}{ Kategori } \\
\hline $1.00-1.85$ & Sangat Buruk Sekali \\
\hline $1.86-2.71$ & Sangat Buruk \\
\hline $2.72-3.57$ & Buruk \\
\hline $3.58-4.43$ & Cukup Baik \\
\hline $4.44-5.29$ & Baik \\
\hline $5.30-6.15$ & Sangat Baik \\
\hline $6.16-7.00$ & Sangat Baik Sekali \\
\hline
\end{tabular}

Hasil penghitungan nilai mean dapat diketahui sebagai berikut:

1. Nilai mean untuk kualitas layanan secara keseluruhan adalah 5.19 termasuk dalam kategori baik.

2. Nilai mean untuk dimensi tangibles adalah 5.10 yang termasuk kedalam kategori baik.

3. Nilai mean dimensi reliability adalah 5.16 yang termasuk kedalam kategori baik.

4. Nilai mean dimensi responsiveness adalah 5.21 yang tergolong baik

5. Nilai mean dimensi assurance adalah 5.23 yang termasuk kedalam kategori baik.

6. Nilai mean untuk dimensi empathy adalah 5.26 yang termasuk dalam kategori baik.

7. Nilai mean untuk kepuasan konsumen secara keseluruhan adalah 5.06 yang termasuk kedalam kategori baik.

\section{Confirmatory Factor Analysis}

Untuk melakukan CFA, penulis menggunakan software SmartPLS 2.0 dengan mempertimbangkan nilai outer loading. Adapun dalam proses CFA ini, terdapat 1 indikator yang di-drop dari penelitian ini, yaitu (REL_1) karena tidak memenuhi cut-off point dari outer loading, yaitu 0,5 . Setelah indikator tersebut di-drop, model dapat dikatakan memiliki nilai fit yang cukup baik.

\section{Pengujian hipotesis}

Untuk melakukan pengujian hipotesis, penulis akan menggunakan analisis regresi linier berganda 
yang akan dilakukan dengan software SPSS 23 . Pertimbangan penggunaan analisis ini adalah bahwa sampel yang diajukan cukup representatif, dan tidak memerlukan path analysis. Adapun hasil dari pengujian hipotesis akan dijelaskan seperti pada Tabel 3.

Tabel 2. Nilai outer loading model penelitian

\begin{tabular}{ccc}
\hline \multirow{2}{*}{ VARIABEL } & & LOADING \\
& INDIKATOR & FACTOR \\
\hline ASSURANCE & A1 & 0.755 \\
& A2 & 0.7488 \\
& A3 & 0.5753 \\
EMPATHY & A4 & 0.6432 \\
& E1 & 0.7765 \\
& E2 & 0.8135 \\
RELIABILITY & E3 & 0.8634 \\
& REL2 & 0.8724 \\
RESPONSIVENESS & REL3 & 0.896 \\
& RESP1 & 0.6271 \\
& RESP2 & 0.8822 \\
TANGIBLE & RESP3 & 0.8634 \\
& T1 & 0.7741 \\
& T2 & 0.7355 \\
& T3 & 0.6811 \\
& T4 & 0.6288 \\
& T5 & 0.526 \\
KEPUASAN & T6 & 0.7764 \\
& T7 & 0.7223 \\
& PUAS1 & 0.8473 \\
& PUAS2 & 0.8268 \\
& PUAS3 & 0.7455 \\
\hline
\end{tabular}

Tabel 3. Uji F

\begin{tabular}{llll}
\hline Model & & F & Sig. \\
\hline 1 & Regression & 21.995 & $.000 \mathrm{~b}$ \\
& Residual & 185.609 & 94 \\
\hline
\end{tabular}

Tabel 4. Hasil pengujian hipotesis

\begin{tabular}{lllc}
\hline & B & Sig & R Square \\
\hline Tan & 0.029 & 0.636 & \\
Rel & 0.707 & 0.039 & \\
Resp & -0.331 & 0.192 & 0.539 \\
Assr & 0.014 & 0.893 & \\
Emp & 0.628 & 0 & \\
\hline
\end{tabular}

Berdasarkan tabel-tabel tersebut diatas maka dapat diambil kesimpulan sebagai berikut:

1. Keseluruhan indikator-indikator pada tiap variabel terbukti sebagai indikator pembentuk variabel kelima dimensi kualitas layanan, hanya satu indikator yang bukan menjadi pembentuk variabel reliability yaitu "pelayanan yang diberikan selalu sama setiap waktu".

2. Dimensi tangible memiliki pengaruh yang positif namun tidak signifikan dengan kepuasan konsumen.
3. Dimensi reliability memiliki pengaruh yang positif dan signifikan dengan kepuasan konsumen.

4. Dimensi responsiveness memiliki pengaruh yang negatif namun tidak signifikan dengan kepuasan konsumen.

5. Dimensi assurance memiliki pengaruh yang positif dan tidak signifikan dengan kepuasan konsumen.

6. Dimensi empathy memiliki pengaruh yang positif dan signifikan dengan kepuasan konsumen.

7. Secara keseluruhan, kualitas layanan berpengaruh positif dan signifikan terhadap kepuasan konsumen.

8. Kualitas memiliki pengaruh terhadap kepuasan konsumen sebesar 53,9\%.

\section{PEMBAHASAN}

\section{Dimensi Tangibles dan Kepuasan Konsumen}

Dari hasil penelitian dapat dikatakan bahwa dimensi tangibles tidak mempengaruhi kepuasan konsumen. Hal ini tidak sesuai dengan pendapat Kotler et al. (1999) yang menyatakan bahwa konsumen Asia seharusnya memiliki pandangan bahwa aspek fisik dari sebuah restoran akan mempengaruhi kepuasan konsumen tersebut. Hal yang menarik pada penelitian ini adalah bahwa justru konsumen tidak menganggap hal tersebut penting.Walaupun pendapat responden secara umum adalah bahwa restoran Jepang di Surabaya telah memiliki aspek tangible yang baik, namun aspek tersebut ternyata belum cukup memiliki pengaruh terhadap kepuasan konsumen.

Wakefield \& Blodgett (1999) menemukan pula bahwa aspek tangibles sebenarnya tidak akan mempengaruhi konsumen dalam mempersepsikan bahwa sebuah layanan itu berkualitas dan memuaskan. Analogi yang bisa diberikan terhadap hal ini adalah kesamaan tingkat pendapatan dari responden, dimana pendapatan responden mayoritas dapat dikatakan cukup tinggi, yaitu di kisaran 10 juta hingga 15 juta rupiah (47\%). Konsumen dengan spending power yang cukup tinggi tentunya akan memilih sebuah restoran berdasarkan preferensi tertentu, dimana seharusnya aspek tangibles atau desain dari restoran tersebut menarik. Lebih lanjut, konsumen-konsumen ini akan membangun kebiasaan untuk menilai bahwa sudah semestinya sebuah restoran memiliki desain yang bagus. Pada akhirnya, desain yang bagus tidak lagi menjadi pengaruh bagi kepuasan konsumen karena konsumen merasa sudah seharusnya sebuah restoran Jepang memiliki desain yang baik. 


\section{Dimensi Reliability dan Kepuasan Konsumen}

Dimensi reliabilitas memiliki peranan yang penting dalam membentuk kepuasan konsumen. Konsistensi dan janji yang diberikan pada konsumen sangat penting untuk ditepati oleh pihak restoran, sebagaimana dijelaskan oleh Kotler et al. (1999) bahwa dimensi ini merupakan titik berat dari layanan menurut perspektif konsumen Asia. Dari wawancara tambahan yang dilakukan penulis terkait dengan hal ini, ditemukan bahwa pada restoran-restoran Jepang yang diteliti penulis, para pelayan memiliki kebiasaan yang baik, yaitu mengingat nama dan preferensi konsumen tersebut. Pada akhirnya, konsumen yang merasa disambut dengan nama akan jauh lebih menghargai, dan konsistensi pelayanan yang diberikan akan sama. Dalam hal ini, konsumen merasa bahwa kebiasaan pelayan-pelayan tersebut menimbulkan perasaan puas, terutama karena konsumen merasa bahwa dirinya penting saat nama dan preferensi konsumen tersebut diingat.

\section{Dimensi Responsiveness dan Kepuasan Konsumen}

Kecepatan pelayanan yang merupakan inti dari dimensi responsiveness tidak memiliki pengaruh terhadap terciptanya kepuasan konsumen. Kotler et al. (1999) menyatakan bahwa konsumen Asia yang melihat waktu sebagai sebuah cycle tidak akan memperhitungkan layanan yang responsif dalam membentuk kepuasan konsumen tersebut. Indonesia, khususnya masyarakat Surabaya yang memiliki karakteristik yang mirip tentunya akan memiliki cara pandang yang serupa.

Penulis melakukan wawancara tambahan untuk menggali lebih lanjut terkait dengan hasil ini.Dari wawancara tersebut, ditemukan bahwa sebagian besar konsumen yang datang ke restoran Jepang memiliki ekspektasi khusus dalam menikmati pengalaman makan. Dalam hal ini, layanan yang terlalu cepat justru tidak terlalu diinginkan oleh konsumen. Sebagai contoh, dalam proses menikmati teppanyaki maupun live sushi making, konsumen akan menghargai show yang oleh chef di station tersebut. Dalam hal ini, justru kecepatan memberikan layanan tidak diinginkan oleh konsumen, justru pengalaman yang dibangun dari restoran tersebut yang tentu saja akan lebih lambat daripada hanya sekedar layanan adalah sesuatu yang diinginkan konsumen dan membuat konsumen tersebut puas.

\section{Dimensi Assurance dan Kepuasan Konsumen}

Dari hasil penelitian ini ditemukan pula bahwa dimensi assurance tidak memberikan pengaruh signifikan dalam pembentukan kepuasan konsumen. Berbeda dengan pandangan dari Kotler et al. (1999), dimensi yang merupakan refleksi dari pengetahuan, jaminan, dan profesionalitas pekerja ternyata tidak memberikan kontribusi pada kepuasan konsumen. Analogi yang dapat diberikan pada fenomena ini adalah bahwa mayoritas dari responden adalah konsumen yang cukup loyal pada restoran Jepang yang merupakan preferensi konsumen tersebut. Frekuensi kedatangan responden pada restoran Jepang adalah 5 - 7 kali dalam sebulan (42\%), yang merupakan angka yang cukup tinggi. Dalam hal ini, konsumen telah memiliki pengetahuan yang baik terkait dengan masakan-masakan Jepang sehingga konsumen merasa tidak perlu untuk menanyakan dan meminta penjelasan karyawan restoran terkait pengetahuan menu.

Konsumen yang loyal pada restoran Jepang yang dapat dikatakan restoran menengah atas juga tidak terlalu mempertimbangkan rasa aman dalam bertransaksi. Konsumen yang loyal, yang bahkan namanya dikenal oleh para pelayan restoran sudah sangat terbiasa bertransaksi di restoran yang bersangkutan. Lebih lanjut, konsumen sangat percaya pada restoran tersebut sehingga tidak terlalu memikirkan keamanan bertransaksi. Pada akhirnya, konsumen tersebut merasa keamanan bertransaksi adalah hal yang sangat biasa sehingga tidak akan memberikan kontribusi pada tingkat kepuasan konsumen tersebut.

\section{Dimensi Empathy dan Kepuasan Konsumen}

Empati karyawan-karyawan restoran akan memberikan kontribusi signifikan terhadap kepuasan konsumen restoran Jepang di Surabaya. Dalam hal ini, hasil penelitian ini mendukung pernyataan Kotler et al. (1999) bahwa konsumen Asia akan memandang penting kepedulian yang diberikan oleh karyawan. Sesuai dengan wawancara tambahan yang dilakukan, konsumen merasa bahwa perhatian personal yang diberikan karyawan sangat disukai karena memberikan perasaan bahwa konsumen tersebut adalah orang yang cukup penting di restoran Jepang. Selain itu, karyawan yang telah mengetahui preferensi konsumen yang menyebutkan menu favorit konsumen tersebut saat melakukan order taking membuat konsumen tersebut merasa bahwa dirinya spesial.

\section{Implikasi Manajerial}

Manajer restoran Jepang dapat menerima keuntungan dengan mempelajari hasil penelitian ini, terutama terkait dengan kualitas layanan dari karyawan yang bekerja di restoran tersebut. Dalam hal ini, konsumen menilai bahwa masing-masing dimensi 
adalah baik. Namun demikian, ada beberapa dimensi yang seharusnya menjadi perhatian bagi para manajer restoran Jepang.

Dimensi reliability yang intinya adalah seberapa konsisten layanan yang diberikan pada konsumen memiliki pengaruh yang paling tinggi dalam memberikan kepuasan konsumen. Dalam hal ini, karyawan restoran yang sudah lama tidak akan memiliki masalah dalam memberikan layanan yang disukai oleh konsumen-konsumen tertentu, sehingga konsumen tersebut akan selalu merasa bahwa layanan adalah konsisten. Namun demikian, ada kemungkinan bahwa karyawan baru tidak akan dapat melakukan hal ini. Oleh sebab itu, untuk menjamin bahwa layanan akan selalu konsisten, restoran perlu membuat sebuah standard operating procedure (SOP) yang jelas dan terbagi atas beberapa langkah kerja. Melalui hal ini, flow kerja karyawan akan menjadi lebih terstruktur sehingga memudahkan pembelajaran bagi karyawan baru restoran Jepang di Surabaya.

Adapun SOP yang diberikan disarankan untuk tidak terlalu rigid atau kaku. SOP yang kaku akan membuat personalisasi dari layanan menjadi berkurang. Hal ini harus menjadi perhatian pula terutama karena dimensi empathy yang berbicara tentang personalisasi dan perhatian bagi tiap-tiap konsumen menjadi sebuah aspek penting yang akan memberikan kepuasan bagi konsumen restoran Jepang di Surabaya. Ruang gerak bagi karyawan harus diberikan sehingga karyawan dapat membuat ekspresi layanan yang personal dan khas bagi tiap-tiap konsumen. Namun demikian, harus terjadi komunikasi yang baik terkait dengan pengenalan konsumen.Untuk itu, disarankan restoran Jepang di Surabaya untuk membentuk sebuah customer data bank untuk memastikan kelancaran komunikasi preferensi konsumen.Hal ini untuk menjamin bahwa tiap-tiap karyawan dapat melihat atau mengakses data preferensi seorang konsumen sebelum melakukan order taking sehingga konsumen merasa bahwa tiap-tiap karyawan di restoran memberikan perhatian personal dan mengingat kesukaan konsumen tersebut.

\section{KESIMPULAN DAN SARAN}

Penelitian ini merupakan penelitian bersifat cross sectional, dimana penulis mendapatkan data secara langsung pada tiap-tiap variabel dalam waktu yang bersamaan. Oleh sebab itu, penelitian ini sebenarnya bersifat korelatif. Untuk dapat melakukan checking pengaruh antar variabel, penelitian selanjutnya sebaiknya menggunakan desain penelitian longitudinal.
Dari pembahasan, ditemukan bahwa hanya dua variabel kualitas layanan yang memiliki pengaruh signifikan terhadap kepuasan konsumen. Oleh sebab itu, sebaiknya dilakukan penelitian tambahan terkait dengan variabel-variabel lain, terutama dimensi tangible karena menurut Kotler et al. (1999), dimensi ini seharusnya merupakan refleksi yang cukup penting dari persepsi konsumen akan kepuasan konsumen di Asia. Karena dimensi tangible yang ada hanyalah terbatas pada desain dan layout dari restoran, maka untuk penelitian selanjutnya disarankan untuk membahas aspek tangible restoran secara lebih luas, sebagai contoh penelitian selanjutnya dapat melihat pengaruh servicescape terhadap kepuasan konsumen.

\section{DAFTAR PUSTAKA}

Caruana, A. (2002). Service Loyalty: The Effects of Service Quality and the Mediating Role of Customer Satisfaction. European Journal of Marketing. 36(7/8), pp. 811-828.

Kotler, Philip. (2003). Marketing Management $\left(11^{\text {th }}\right.$ ed.).New Jersey: Prentice Hall International, Inc.

Kotler, Philip, Ang, Swee H., Leong, Siew M., \& Tan, Chin T. (1999). Marketing Management: an Asian Perspective ( ${ }^{\text {nd }}$ ed.). Singapore: Prentice Hall International, Inc.

Kotler, Philip, \& Armstrong, Gary. (2003). Principles of Marketing $\left(10^{\text {th }}\right.$ ed.). New Jersey: Prentice Hall International, Inc.

Kotler, Philip, \& Keller, Kevin L. (2009). Marketing Management (1 $13^{\text {th }}$ ed.). New Jersey: Prentice Hall International, Inc.

Lupiyoadi, R., \& Hamdani, A. (2006). Manajemen Pemasaran jasa. Jakarta: Salemba Empat.

Stevens, P., Knutson, B., \& Patton, M. (1995). Dineserv: a Tool for Measuring Service Quality in Restaurants. Cornell Hotel and Restaurant administration Quarterly. 36, pp. 56-60.

Tjiptono, F. (2005). Pemasaran Jasa. Malang: Bayu Media.

Wakefield, L. K., \& Blodgett, G.J. (1996). The Effect of the Servicescape on Customer Behavior Intentions in Leisure Service Setting. Journal of Service Marketing, 10(6), pp. 45-61.

Zeithaml, V.A., \& Bitner, M.J. (2009). Service Marketing ( $5^{\text {th }}$ ed.). Singapore: The McGrawHill Companies, Inc.

Zeithaml, V., Bitner, M., \& Gremler, D. (2006). Services Marketing. Integrating Customer Focus Across the Firm ( $4^{\text {th }}$ ed.). Singapore: McGrawHill International Edition. 